\title{
LIBRARY AND INFORMATION SCIENCES EXHIBITION
}

\author{
By D. L. SMITH, Librarian \\ Oxford College of Technology
}

\begin{abstract}
IN Great Britain library work is still generally considered to be one of the gentler professions, even more perhaps among the dreaming spires of the "home of lost causes" than in industrial cities. Librarianship has not yet been recognized as the library science of the United States. It may seem surprising, therefore, that Oxford should be the centre for an exceptionally comprehensive exhibition of literature devoted to library and information sciences. It is less surprising that a large proportion of the material displayed should have been American, especially in the documentation and information retrieval aspects which were particularly emphasized.
\end{abstract}

The exhibition was arranged by the Documentation and Supply Centre of Robert Maxwell and Co., Ltd., in their Oxford bookshop below the new buildings of Magdalen College, during July 29-31. Its opening on the first afternoon was attended by a representative cross-section of the academic, technical and scientific library, information officer and book-selling professions and, in the absence of Mr. Robert Maxwell on parliamentary duties, the objectives were explained by Mr. Cadness Page, who has recently become managing director of the firm's book-selling service. Mr. Page briefly outlined the new imperative need of research workers in every field for rapid, accurate and thoroughly comprehensive literature searches, and said it was fortunate that the much-publicized information explosion had been followed by the introduction of computers, automatic control and punched-card techniques into the processes of documentation and information retrieval. This was the first exhibition of its kind to be held in Britain, and as such was a vital contribution to scientific research. A special value of the occasion lay in the opportunities for informal discussion of present-day problems among the participants.

Tribute was paid to the work of Mr. Hans Zell, in charge of Maxwell's Documentation and Supply Centre, who was responsible for collecting the extremely wide range of literature on display. The office of the Centre, with its permanent collection of bibliographical tools, unrivalled except in the larger university libraries, was also open to visitors; likewise the new warehouse (with storage space for more than three million volumes) and offices, now nearing completion half a mile away at Headington Hill Hall on the site shared with Pergamon Press, which have been planned for the improvement of the firm's nationwide and international service for the supply of books to libraries. Mr. Zell is already well known as editor of a number of other useful lists and bibliographies distributed to librarians, including New Reference Tools for Librarians of which the third annual volume has just appeared; subject bibliographies on a wide range of topics, such as cartography, nutrition, graphic arts and industries, quality control and biophysics, all international in their coverage; and the new 300-page International Bibliography of Non-periodical Literature on Documentation and Information, the publication of which coincided with the opening of the exhibition. More specific in its content, the latter gives full details of more than 1,500 items published since 1930 (Russian material being excluded), with appendixes devoted to relevant periodicals and associations; arrangement is alphabetical, with a manually produced, permuted title index, and it is planned that a more useful subject index, produced by computer, will be incorporated in a later edition.
Another service operated from the same Documentation and Supply Centre, and now firmly established, is the punched-card system giving advance information on new books, batches of cards being distributed free to individual libraries on the basis of their own subject coverage.

In support of the exhibition the same editor has issued an attractive and clearly laid-out catalogue of its contents, with a supplement to bring it right up to date-nearly 800 books and pamphlets from eighteen countries altogether. While the emphasis is on modern methods of storing and speedily retrieving information in print and in every recorded form-the mechanized systems available for cataloguing, indexing, storage, location and extractionthe exhibition also embraced every branch of library science and librarianship in the more traditional sense, and includes a comprehensive range of recently published bibliographies, encyclopaedias and other reference books in every field likely to be of use to the librarian or reader in search of information. All the material has appeared since the beginning of 1963 , and there were a few proof copies of books to be published shortly, such as the next two volumes in the "How to Find Out" series from the Commonwealth and International Library of Science, Technology, Engineering and Liberal Studies, of Pergamon Press. One section of the exhibition was devoted to specimen copies of recent journals dealing with information processing, storage and retrieval.

Perhaps the most notable feature of the display and its accompanying catalogue was the success of the efforts made to include a great deal of ephemeral, obscure and out-of-the-way material, such as bibliographies or specialized papers issued by libraries, schools of librarianship, research establishments and some of the less-well-known Government organizations. Many of these are unlikely to be listed in regular national bibliographies or publishers' catalogues. The means by which so many obscure pamphlets had been traced and assembled was a mystery to at least one librarian, and the opportunity of examining so much material of this nature in itself made the whole operation well worth while. This achievement was all the more remarkable in view of the fact that some of the libraries originally approached for details of their publications apparently did not reply at all. Of the catalogue there can be only one small criticism: a contents list of the broad subject headings governing its arrangement would have been helpful, unless it is realized that they are in Universal Decimal Classification order.

From such a wealth of material it is impossible to pick out any items more worthy of notice than others; the smallest and least conspicuous were often as valuable as the largest tomes. Among the latter J. G. Davis's two interesting volumes on Cheese seemed at first sight out of place, until it was realized that Volume 2 consists ontirely of an annotated bibliography with subject index.

It was perhaps a little unfortunate that the exhibition should have been held at the peak of the holiday season, when many librarians and information scientists were far away; and undoubtedly in London it would have attracted even more attention. The sponsors have announced, however, that it is being repeated at the Library Association Conference at Eastbourne in September, and in Scotland at Maxwell's Glasgow bookshop and Cairns Brothers of Edinburgh; possibly also at Aslib headquarters in London. 